An investigation into the attraction and completion rates of MOOCs

Sergey Kruchinin

Noyabrskiy Oil and Gas Institute (branch) of TIU in Noyabrsk, Russia

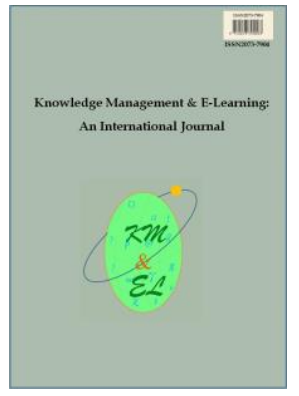

Knowledge Management \& E-Learning: An International Journal (KM\&EL) ISSN 2073-7904

Recommended citation:

Kruchinin, S. (2019). An investigation into the attraction and completion rates of MOOCs. Knowledge Management \& E-Learning, 11(1), 38-58. https://doi.org/10.34105/j.kmel.2019.11.003 


\title{
An investigation into the attraction and completion rates of MOOCs
}

\author{
Sergey Kruchinin* \\ Branch of Economics, Management and Natural Sciences \\ Noyabrskiy Oil and Gas Institute (branch) of TIU in Noyabrsk, Russia \\ E-mail: kruchinin.s.v@bk.ru \\ *Corresponding author
}

\begin{abstract}
Many studies are dedicated to MOOCs, however there was no clear answer to what makes a particular MOOC popular. This study was an attempt to answer this question. Data about MOOC distribution was collected for this research, including category data, university types and MOOC platforms, data regarding MOOC popularity in different time periods, and regarding MOOC completion rates. It was determined that university type and MOOC category did not influence the number of enrolled students. However, Coursera and edX attracted many more students than the other MOOC platforms. Besides these facts, the number of students who really completed the course was much higher for the MOOCs created by top universities. Thus, courses by top universities did not have higher enrolment, however they became more well-known because of the number of students who really took them. The assessment format had a high influence on the completion rates as well. A traditional MOOC format and auto grading caused higher completion rates than other formats. Thus, popular MOOCs could be created in any category by each university, however Coursera and edX's courses attracted more students, and an auto grading course format involved them in studying the course.

Keywords: MOOC; Enrolment; Completion rates; Attraction; Higher education

Biographical notes: Dr. Sergey Kruchinin is Ph.D. in Philosophy and lecturer. His main scientific interests are focused on online learning and education, MOOCs; and interdependence between society and modern technologies.
\end{abstract}

\section{Introduction}

Since 2012, MOOCs have played an important role in education and social development (Pappano, 2012). During the last couple of years, the number of academic discussions about MOOCs have been growing rapidly. Universities from all over the world have been involved in the processes of creating and publishing new MOOCs (O'Connor, 2014). Every year new students get involved in studying through MOOCs. At present the two biggest MOOC platforms, Coursera (https://www.coursera.org) and edX (https://www.edx.org), provide more than 1,000 courses of different types and on different subjects. Thousands of students take courses from these two platforms. (Kobas, 2014). MOOCs are an important phenomenon in social development and the technologies of learning (Liang, Jia, Wu, Miao, \& Wang, 2014). The vast majority of the papers in social sciences on this field are dedicated to learning technologies or to specific social 
characteristics and the significance of MOOCs (Maringe, \& Sing, 2014; Chaturvedi, Goldwasser, \& Daume, 2014).

Most MOOCs are aggregated by MOOC providers such as Coursera, edX and Udacity. In September of 2017, there were about 3,000 MOOCs (including self-evaluated) on Coursera, edX and Udacity. However, at present there are a lot of small MOOC providers including some not from the USA. These small platforms usually provide about 20-40 courses that can be very informative. It is important to highlight that MOOC providers have their own requirements for courses available on their platform, which leads to some standardization of published courses. Separate providers have their own specific requirements, which can in some cases become competitive advantages. Simultaneously, several studies have shown that the vast majority of foreign students $(83 \%)$ taking a MOOC have already finished two to four years of higher education (Emanuel, 2013) and 55\% of students who completed a course had a master's degree or higher (Chernova, 2013)

In this research study, the differences between the types of students who choose MOOCs will not be discussed. Instead, this paper will focus on the different types of MOOCs that attract students. Some studies have suggested that students attracted by MOOCs were determined by their ideology, which can be described as innovation, disruption and progress' (Gaebel, 2013). This ideology was strongly associated with technological progress, created in California's Bay Area by the founders of Coursera, edX and other MOOC platforms. Moreover, the first online courses, produced by Stanford University, were focused on technology. Then other top universities started to produce MOOCs. The vast majority of them were technology- or engineering-focused. Moreover, the first MOOCs duplicated the same courses in the universities by which they were provided. This fact attracts a lot of attention to these courses, because they were free or cheap opportunities to 'look inside' particular courses of top universities without any exams or other restrictions, including moving to foreign countries. This beginning has become the background of the main ideology of MOOCs, which still influences MOOC production, organization and attraction of a certain type of students (Rodriguez, 2013). Coursera and edX promise superior education, even 'the world's best education' or 'empowering learning in the classroom and around the globe'. Morozov (2013) has called their approach 'Silicon Valley solutionism', which assumes that higher education cannot be understood as 'a predefined set of problems accompanied by corresponding technological remedies’ (Knox, 2016b).

Nevertheless, the popularity of MOOCs mean that MOOCs have become one of the major modern markets in e-learning. Undoubtedly, the MOOC market is not a typical e-learning market, it has its own specifics. MOOC producers have business goals. These goals will not be discussed in this study, but were assumed to include making profits on courses via certificates and additional material sales, such as books on Amazon by the MOOC lecturers. Moreover, MOOC producers can achieve reputational goals such as university popularity. Thus, courses have to compete with each other for both enrolled students and for students who will really take and complete the course. It is very important to analyse enrolment and completion rates, because the second statistic for courses of all the types in the year 2013 was lower than $10 \%$ of the total number of students. In this study, the factors that affect completion rates were analysed. For example, completion rates were much higher for automatic grading courses than for peer grading (Jordan, 2015). Thus, this research study analysed which MOOCs attracted students and how they did it, and what determined course completion rates. 
The main purpose of this study was to find MOOC characteristics that influenced course enrolment and on the number of students who complete the course. Previously some MOOC characteristics were observed in literature review, however, this research focused on measurable variables that influenced MOOC popularity. Thus, the main research questions (RQs) were:

RQ1: Which courses are introduced more frequently than others?

RQ2: What MOOCs are the most popular?

RQ3: Which MOOC characteristics affected the number of enrolled students?

RQ4: Which parameters determined MOOC completion rates?

\section{Literature review}

Morozov (2013) called the main idea of MOOCs 'Silicon Valley solutionism'. MOOC enrolment was determined by its origins. The main idea of MOOCs was that the high educational standards provided by the top universities, which were based on principles of rationality, would guarantee a high educational level in different scientific fields (Giannella, 2015). However, these educational standards assume one correct answer or a definite set of answers, while the ordinary educational paradigm is based on critical thinking, reasoning and arguing (Chandler, 2002). Therefore, in some scientific areas it is impossible to determine the accuracy of the answer as the main criterion of a successful course. Undoubtedly, knowledge is an important part of education in any scientific field. However, the educational process cannot be reduced just to the process of gaining knowledge (Kanuka, 2008). The most reasonable critique of this issue has showed that there was a lack of moral principles in this educational approach, which were strongly correlated with the dialogue between lecturer and students. Simultaneously, the global scale of the MOOCs does not allow for a direct dialogue between the professor or lecturer and their students (Knox, 2016a). Moreover, there are a lot of opinions about proper communication between lecturer and student in MOOCs. Some researchers claim that communication is necessary and there is not enough at present (Allen, \& Seaman, 2014), however others argue that this communication is redundant. This problem was partly solved by peer and auto plus peer assessments. Moreover, many lecturers have started to communicate with their students more than in the beginning of MOOCs. This could possibly be correlated with the lower number of enrolled students. The fewer students, the more easily the lecturer can manage them.

Some critics metaphorically compare the main idea of MOOCs with the binary logic of the Internet as 'salvation or destruction' (Johnston, 2009) or even with the fast food industry and warnings about the 'uncontrolled spread of junk education' (Baggaley, 2014). However, it is important to highlight that these critical articles were published before Coursera's specialization became widespread. Moreover, Udacity started its own long-term educational programs and edX started serial courses and MicroMasters programs, which attracted other students and provides educational opportunities more similar to ordinary education. Some of these long-term programs, specializations and serial courses have restrictions on the number of participants, which helps to develop intragroup communication and dialogue between the lecturer and students. The vast majority of these courses, especially with a restricted number of participants, required payment. These courses were not on the focus of this research, because they had issues other than those discussed in the current study. 
An interesting fact is that the main idea of MOOCs of edX allows for taking courses 'at your place, at home or in a cafe'. However, both Coursera and edX 'display images of campus real-estate atop the various pages that introduce their partnering educational institutions' (Knox, 2016b). The main purpose of these images is to induce a sense of belonging in the MOOCs' students. This sense can increase both the number of enrolled students and the number of students who actually take the course.

In literature review is important to underline several specific issues of MOOCs. The first of these issues is 'fundamental orthodoxy limits' caused by the 'openness' concept of MOOCs', which assumes affordability, as well as technological, language and other important educational options (Knox, 2014). However, it is impossible to provide a high level of education comparable to a typical education or long-term e-learning programs at the same universities under these circumstances (Cirulli, Elia, \& Solazzo, 2017). Undoubtedly, many online courses provided by high-level universities are better and more informative than the ordinary courses by low-level ones. Nevertheless, the comparison between high-level and middle-level universities is much more complicated.

Secondly, MOOCs have been associated only with the top universities for a long time, however, at present the vast majority of courses are affiliated with non-elite universities (Peters \& Seruga, 2016). In this research study, the influence university type had on the number of enrolled learners was analysed. Whether university type influenced MOOC completion rates was also researched.

Thirdly, the number of MOOCs in arts and humanities is very limited. Evans \& McIntyre (2014) showed that only 7\% of the total quantity of MOOC is dedicated to humanities. This fact can be explained by key differences between humanities and other disciplines. Humanities usually do not assume a definite right answer. 'They teach a way of thinking' that demands a dialogue between lecturer and students. Therefore, the standard way MOOCs assess knowledge are not ideal for the humanities. This problem was solved by peer and auto plus peer assessments, which were extremely useful in arts and humanities courses. In this study, how the MOOC category influenced the number of enrolled students was analysed, and if there was an effect, what the effect was for different categories.

Fourthly, founders of MOOCs have assumed that students are self-directing and rational, which determines their promotion strategy and delivery of the courses (Knox, 2016b). Thus, MOOC students have to enrol only in the courses that they need and are interested in. This hypothesis is obviously unrealistic, as the vast majority of students (or human beings in general) are not purely rational. Many students enrolled in MOOCs and afterwards totally forgot about it. Therefore, the distribution of MOOCs is asymmetric in the same way as other information distribution (Yuan \& Powell, 2013). Some students who really wanted to take the course might not have information about it. Simultaneously, some students had other ideas about the courses they enrolled in. As a result, the number of enrolled students might not match the number of the students who actually took and completed the course.

Nevertheless, one of the main characteristics of MOOCs is their affordability for students of different kinds, including underprivileged students (Evans \& McIntyre, 2014). Since the research of Evans and McIntyre was published in 2014, purchasing power parity has significantly changed. For example, the rate of the Russian rubble has reduced twice. As a result, the average cost of MOOCs (with verified certificate) provided by Coursera and edX, has reached half of the average monthly salary in Russia. Moreover, Coursera started specializations, which are available only for a fee. Usually courses included in specializations are available only for a fee as well. In addition, some 
universities such as MIT provide different learning conditions for students who have paid for a verified certificate versus those who did not. In this study, the differences between MOOCs and the number of the students due to the paid format has not been discussed. To exclude this factor, only courses that were available for free were analysed.

Many recent studies were dedicated to learners' specifics that determined their MOOC involvement (El Said, 2017), or to specifics of massive courses (Van Der Sluis, Van Der Zee, \& Ginn, 2017). However, this research concentrated on the problem of which courses attracted the most students, and which factors about MOOCs determined students' choices.

\section{Method}

In this paper information about all available courses on Coursera and edX in September 2017 was collected and analysed. Courses in each category according to information on the MOOCs' platform were counted and duplication was not excluded. Overall 2,236 courses on Coursera and 879 courses on edX were examined. This data was used for studying RQ1.

For course classification, Coursera categories, excluding personal development, were used because they are easily understood. The personal development category was not analysed due to the inability to compare it with a similar category on edX. Overall in this research study, nine categories were examined: arts and humanities, business, computer science, data science, life science, math and logic, physical science and engineering, social sciences and language learning. Moreover, the research specified university type. Universities were classified into 'top universities' and 'others'. The top universities were comprised of those that took a top 50 overall world university ranking, plus small universities that were among the ten best universities in the world in their field. The top universities were labelled with a 1 , and the others with a 0 .

In this research study, 132 MOOCs were analysed more deeply. For these courses, data about its providers was collected. Overall, 7 MOOC platforms were included in the research. These were Coursera, edX, FutureLearn, Open2Study, Udacidy and Iversity. The MOOC platforms were labelled from 1 to 7 according to this list.

Freely available information about the number of enrolled students and the completion rates of the different courses was used in this research study. All information used in this study was available on the course pages on the Coursera and edX sites, on the KatyJordan (http://www.katyjordan.com/MOOCproject.html) webpage and on specialized sites dedicated to MOOC data. The university ranking was determined according to QS TOPUNIVERSITIES (www.topuniversities.com). Data collected from different sources was provided in the Appendix I.

SPSS 23 was used for data analysis. In this research study, non-parametric tests for $\mathrm{K}$ independent samples were applied, including the Kruskal-Wallis $\mathrm{H}$ test, Jonckheere-Terpstra test and median test, linear regression and regression for categorical data. 


\section{Findings}

\subsection{RQ1: Which courses are introduced more frequently than others?}

In this research study, representative data for MOOCs was collected to disprove the hypothesis about the prevalence of computer science, data science and science courses. Previously, Evans and McIntyre (2014) had shown that there were few humanities courses. The unequal distribution of MOOCs could shift the number of enrolled students for each course. In this RQ, it would be shown that courses were represented equally.

Data collected about courses in different categories for the platforms Coursera and edX was classified into two groups: courses provided by top universities and others. The total number of currently available courses provided by top universities (in September 2017) on Coursera was 220 and on edX, 196. These figures are quite similar, however, the total number of courses on Coursera is 2.5 times more than on edX. For each category the total number of courses and average values were calculated. The figures in brackets for the 'number of courses' columns represented the percentage of courses in each particular category within the total number of courses, and for the 'number of courses provided by top universities' columns, the percentage within the total number of courses in this category for each platform. Average shares were calculated using an average mean for each column.

Previously, Kobas had assumed a reduced interest in MOOCs (2014). Simultaneously, Evans and McIntyre (2014) had found that in March 2013 there were only 65 humanity courses provided by Coursera and edX combined, which was $17 \%$ of the total number of courses. The total number of courses in March 2013 was 382 (8 times fewer than in September 2017). In other words, the interest in MOOCs has not reduced, and has even grown since 2014. The data is represented in Table 1.

Table 1

The number of courses provided by Coursera and edX in September 2017

\begin{tabular}{|c|c|c|c|c|}
\hline \multirow[b]{2}{*}{ MOOC categories } & \multicolumn{2}{|c|}{ Coursera } & \multicolumn{2}{|c|}{ edX } \\
\hline & $\begin{array}{l}\text { Number of } \\
\text { courses }(2236)\end{array}$ & $\begin{array}{l}\text { Number of courses } \\
\text { provided by top } \\
\text { universities }(220)\end{array}$ & $\begin{array}{l}\text { Number of } \\
\text { courses }(879)\end{array}$ & $\begin{array}{l}\text { Number of courses } \\
\text { provided by top } \\
\text { universities (196) }\end{array}$ \\
\hline Arts and Humanities & $203(9.1 \%)$ & $37(18.2 \%)$ & $88(10 \%)$ & $38(43 \%)$ \\
\hline Business & $644(28.8 \%)$ & $38(5.9 \%)$ & $139(15.8 \%)$ & $41(29 \%)$ \\
\hline Computer Science & $359(16.1 \%)$ & $34(9.5 \%)$ & $232(26.4 \%)$ & $24(10 \%)$ \\
\hline Data Science & $183(8.2 \%)$ & $18(9.8 \%)$ & $93(10.6 \%)$ & $28(30 \%)$ \\
\hline Life Science & $194(8.7 \%)$ & $18(9.3 \%)$ & $70(8 \%)$ & $18(26 \%)$ \\
\hline Math and Logic & $69(3.1 \%)$ & $15(21.7 \%)$ & $52(5.9 \%)$ & $2(4 \%)$ \\
\hline $\begin{array}{l}\text { Physical Science and } \\
\text { Engineering }\end{array}$ & $217(9.7 \%)$ & $25(12 \%)$ & $82(9.3 \%)$ & $26(32 \%)$ \\
\hline Social Sciences & $305(13.6 \%)$ & $31(10.2 \%)$ & $100(11.4 \%)$ & $19(19 \%)$ \\
\hline Language Learning & $62(2.8 \%)$ & $3(4.8 \%)$ & $23(2.6 \%)$ & $0(0 \%)$ \\
\hline Average Value & 248.4 & $24.4(11.3 \%)$ & 97.7 & $21.8(21.5 \%)$ \\
\hline
\end{tabular}


The data represented in Table 1 shows some important issues. First of all, the categories with the greatest number of MOOCs was different for Coursera (business, $28.8 \%$ ) and edX (computer science, 26.4\%), however, these two categories took the top positions in all analyses. Results for the other categories were rather similar. In third place came social sciences (11.4-13.6\%), then arts and humanities (9.1-10\%), data science (8.2-10.6\%) and physical science and engineering (9.3-9.7\%). Secondly, the average number of courses provided by top universities was about twice as high for edX courses as it was for Coursera $(21.5 \%$ to $11.3 \%)$, however, the total number of these courses was a little bit higher for Coursera. Thirdly, it was found that the top universities provided extremely few courses in the category language learning $(0 \%)$ on edX and $4.8 \%$ on Coursera. Simultaneously, $21.7 \%$ of courses on Coursera in the field of math and logic were provided by the top universities (and just 4\% on edX); $29 \%$ of courses on edX were in the field of business, and $5.9 \%$ on Coursera.

\subsection{RQ2: What MOOCs are the most popular?}

Previously, the first online courses provided by Stanford had about 100,000 enrolled students (Kobas, 2014). Undoubtedly, the vast majority of students did not complete these courses. Moreover, Jordan (2013) found that the average completion rate of Coursera's MOOCs in 2013 was below 10\%, however, in 2015 this percent increased to $14 \%$ (Jordan, 2015). According to the results of Jordan's (2015) research, completion rates were $4.6-19.2 \%$ for auto grading, and $0.7-10.7 \%$ for peer grading.

The most popular MOOC of all the time is the course by the University of California San Diego 'Learning How to Learn: Powerful mental tools to help you master tough subjects' on the Coursera platform, which launched in 2012. In total, 1,192,697 students have enrolled in the course since its inception (The 50 most popular MOOCs of all time, 2015). Second place is taken by the course 'Machine Learning: Master the Fundamentals' by Stanford University. The course was no longer available at the time this article was being written. In third place is the course ' $\mathrm{R}$ Programming' by Johns Hopkins University, with 952,414 enrolled students (Appendix I, Table a). At present Johns Hopkins University has presented two more additional courses on the same topic: 'The R programming Environment' and 'Advanced R Programming'. Both of these courses attracted many learners. Among the ten most popular MOOCs of all the time, there have been three courses dedicated to data science, two to computer science, two to arts and humanities, two to business, and one to language learning. Among the fifty the most popular MOOCs, a high percentage of them are dedicated to computer science (26\%), with the second most focusing on arts and humanities topics (20\%), and the third most on business topics (18\%). Just 6 courses (12\%) have been dedicated to data science. The data is represented in Table 2.

In 2014 the most popular course was the same as the all-time most popular, and in second place was the 'R Programming' course. In third place was the 'Introduction to Finance' course by the University of Michigan, which is included in the top university list. Moreover, there were two 'Introduction to Computer Science' courses, one by Harvard University and the other by the University of Virginia (not a top university) provided on Coursera and Udacity, respectively. Thus, it can be concluded that in the same year similar courses can both be popular, even if one of them was provided by a top university and the other by a non-top university. The vast majority of the most popular MOOCs in 2014 were business related. In second place were arts and humanities courses, and in third, data science. In all of the data series, the business, arts and humanities, computer science and data science categories were represented more widely than others. 
Moreover, among the most popular courses of the year was just one course 'Nutrition and Health: Food Safety' in the category of life sciences.

Table 2

The quantity of the most popular courses in different categories

\begin{tabular}{lllll}
\hline \multicolumn{1}{c}{ Categories } & All the time & 2014 & $2015 \mathrm{C}$ & 2016 \\
\hline Arts and Humanities & $10(20 \%)$ & $3(30 \%)$ & $2(20 \%)$ & $5(50 \%)$ \\
Business & $9(18 \%)$ & $4(40 \%)$ & $2(20 \%)$ & $1(10 \%)$ \\
Computer Science & $13(26 \%)$ & $1(10 \%)$ & $3(30 \%)$ & $2(20 \%)$ \\
Data Science & $6(12 \%)$ & $2(20 \%)$ & $3(30 \%)$ & $1(10 \%)$ \\
Life Sciences & 0 & 0 & 0 & $1(10 \%)$ \\
Math and Logic & $4(8 \%)$ & 0 & 0 & 0 \\
Physical Science and & $1(2 \%)$ & 0 & 0 & 0 \\
Engineering & $3(6 \%)$ & 0 & 0 & 0 \\
Social Sciences & $4(8 \%)$ & 0 & 0 & 0 \\
Language Learning & & & & 0 \\
\hline
\end{tabular}

It was impossible to find high quality data about the most popular courses of 2015. Therefore, data was collected about the most popular MOOCs on Coursera. The three top positions on this list were extremely predictable: 'Learning How to Learn: Powerful mental tools to help you master tough subjects', ' $\mathrm{R}$ Programming' and 'Machine Learning: Master the Fundamentals'. However, the fourth position was not expected. In fourth place was the course 'The Data Scientist's Toolbox', provided by Johns Hopkins University.

In 2016 the most popular courses were self-paced ones. The most popular MOOC was 'Learning How to Learn: Powerful mental tools to help you master tough subjects'. In second place was the course 'Cryptography I' on Coursera by Stanford University. In third place was 'R Programming'. Thus, the most popular courses of all the time were not the most popular courses in each year. There were many new courses that became extremely popular in each particular year.

Characterizing the differences in university type, it should be highlighted that in all the years, excluding 2016, top universities have prevailed. A high percentage of top universities in the sample was observed in 2015 on Coursera. However, in 2016 other universities prevailed in the most popular MOOCs of the year (Fig.1).

Similar diversification could be observed among MOOC platforms. A high percentage of the most popular courses were published on Coursera. This was true for all data series in this study. EdX was took second place and all the other platforms had more or less similar percentages (Table 3). It is important to highlight that the cumulative percentage of the other platforms in 2014 and 2015 was 40 and 30, respectively. Moreover, each of these platforms had 3 or 4 of the most popular MOOCs.

New courses provided by the top universities, or even new sessions of existing courses attracted a lot of students. For example, 'Introduction to Computer Science' by Harvard University attracted significantly more than 50,000 students in 2016. Moreover, 
these courses were translated into several foreign languages by some scientific communities.

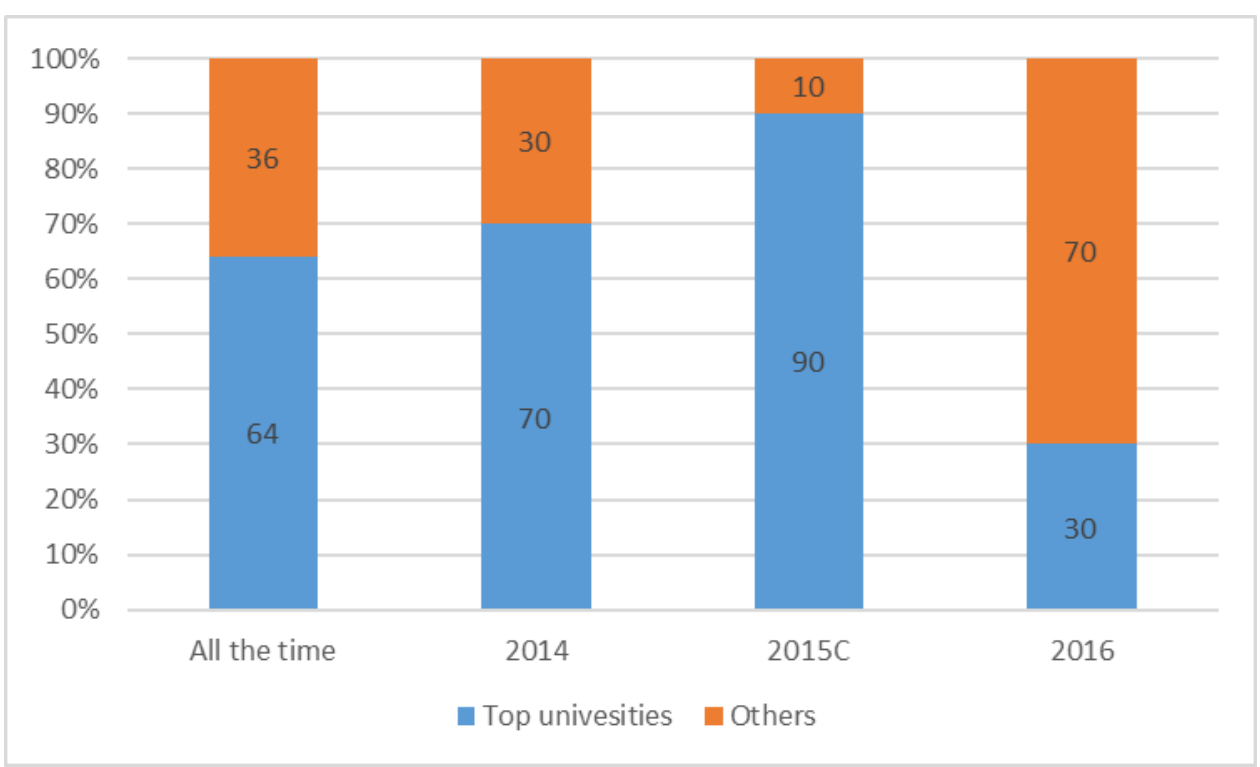

Fig. 1. Percentage of top universities and others with the most popular MOOCs

Table 3

The quantity of the most popular MOOCs on different platforms

\begin{tabular}{lcccc}
\hline Platforms & All the time & 2014 & 2015 & 2016 \\
\hline Coursera & 36 & 5 & 6 & 6 \\
edX & 9 & 1 & 1 & 3 \\
FutureLearn & 2 & 0 & 1 & 0 \\
Open2Study & 0 & 2 & 0 & 1 \\
Udacidy & 2 & 2 & 0 & 0 \\
Iversity & 1 & 0 & 2 & 0 \\
\hline
\end{tabular}

Nevertheless, the vast majority of MOOCs attracted 10,000-55,000 students, with an average number of about 25,000. These courses were provided either by top universities such as Pennsylvania University and MIT, or by other universities such as Ohio State University.

\subsection{RQ3: Which MOOC characteristics affected the number of enrolled students?}

Previously, the following independent variables were described: MOOC category, university type and MOOC platform. According to each of these variables, independent parts of the sample were classified. Several non-parametric tests for $K$ independent samples were used to find significant differences between the groups. The KruskalWallis $\mathrm{H}$ test, Jonckheere-Terpstra test and the median test were applied to the most popular courses of all the time to define the differences between parts of the sample. 
These tests were applied to all independent variables, however, none of them indicated any significant differences. Using the MOOC platforms as the basis of group diversification, type I error probability was about $30 \%$, using university type, $26 \%$, and using MOOC category, $60 \%$. Thus, the hypothesis about the diversification of the groups according to one of the selected variables was rejected.

The same groups were classified for the extended data set. The new data set included 50 of the most popular MOOCs of all the time and 84 average MOOCs with the same parameters of category, university type and MOOC platform. Thus, the new sample could be considered as representative. For 134 MOOCs, in non-parametric tests for K independent samples, including the Kruskal-Wallis H test, Jonckheere-Terpstra test and median test, significant differences between the groups for each variable were found. Therefore, CATREG, Regression for Categorical Data, was used to find the dependencies between MOOC category, university type, MOOC platform and the number of enrolled students. The results are represented in Tables 4 and 5.

Table 4

The number of courses provided by Coursera and edX in September 2017

\begin{tabular}{lccccc}
\hline Measures & Sum of Squares & Df & Mean Square & F & Sig. \\
\hline Regression & 69.433 & 12 & 5.786 & 10.923 & 0 \\
Residual & 63.567 & 120 & 0.53 & & \\
Total & 133 & 132 & & & \\
\hline
\end{tabular}

ANOVA analysis showed that the regression and model coefficients were statistically significant, with an adjusted R square of 0.474 . In other words, the model was good enough for an analysis of its results. In this model university type was labeled 1 for the top universities and 2 for others. Other labels for the variables were the same as described in the methods section.

Table 5

Regression coefficients for Categorical Data

\begin{tabular}{lccccc}
\hline & Beta & $\begin{array}{c}\text { Bootstrap (1000) Estimate } \\
\text { of Std. Error }\end{array}$ & Df & F & Sig. \\
\hline Category & 0.295 & 0.061 & 8 & 23.556 & 0 \\
U_Type & -0.187 & 0.08 & 1 & 5.519 & 0.02 \\
Platforms & -0.589 & 0.095 & 3 & 38.712 & 0 \\
\hline
\end{tabular}

The results showed that the top universities attracted a few more MOOC learners than other universities. However, this variable influenced the number of enrolled students the least. The MOOC platform had the most impact on the number of students. The most popular platforms, such as Coursera and edX, enrolled significantly more students for all their courses than other platforms, even though these other platforms had MOOCs rated among the most popular courses of all the time and for particular years. The variable category could not be interpreted as easily as university type and MOOC platform, because it represented different groups of courses, but none of them were better or more well-known than the others. Thus, it should be represented as additional data (Table 6). 
The average number of enrolled learners was at its most in the category math and logic, however there was just one MOOC by a top university and one by others. In second place were computer science courses, with an average enrolment of 62,993.63 students. Their share of the analyzed MOOCs was equal for top universities and others (20\%). Top universities had the largest share of enrolled learners among all observed categories. For other universities, the largest share of learners enrolled in arts and humanities courses. This category was the fourth-largest according to average enrolment. The third-largest category was physical science and engineering MOOCs, however, courses in this category were not presented by other universities. The least number of learners enrolled in language learning courses. None of these MOOCs were presented by top universities. A more or less equal number of students enrolled in business and life sciences courses. These categories were the second and the third least popular categories, respectively. In the seven categories, excluding social sciences and language learning, top universities attracted significantly more students. However, the diversification of courses between categories was quite different from the two types of universities. Nevertheless, all categories attracted many students, and there was no strict correlation between the number of courses and average enrolment.

Table 6

The number of courses and average enrolment in each MOOC category

\begin{tabular}{llllll}
\hline \multicolumn{1}{c}{ Categories } & \multicolumn{2}{c}{ Top universities } & \multicolumn{2}{c}{ Others } & Average for \\
& $\begin{array}{l}\text { Number of } \\
\text { courses }\end{array}$ & $\begin{array}{l}\text { Average } \\
\text { enrolment }\end{array}$ & $\begin{array}{l}\text { Number of } \\
\text { courses }\end{array}$ & $\begin{array}{l}\text { Average } \\
\text { enrolment }\end{array}$ & $\begin{array}{c}\text { MOOCs } \\
\text { category }\end{array}$ \\
\hline Arts and Humanities & $9(18 \%)$ & 81954 & $7(23.3 \%)$ & 26895 & 57865.69 \\
Business & $3(6 \%)$ & 90284 & $5(16.7 \%)$ & 8669 & 39274.63 \\
Computer Science & $10(20 \%)$ & 80730 & $6(20 \%)$ & 33433 & 62993.63 \\
Data Science & $8(16 \%)$ & 59647 & $3(10 \%)$ & 35537 & 53071.55 \\
Life Sciences & $7(14 \%)$ & 45471 & $1(3.3 \%)$ & 1180 & 39934.63 \\
Math and Logic & $1(2 \%)$ & 86320 & $1(3.3 \%)$ & 47000 & 66660 \\
Physical Science and & $7(14 \%)$ & 58777 & 0 & 0 & 58777 \\
Engineering & & & & & 51279.5 \\
Social Sciences & $5(10 \%)$ & 49315 & $5(16.7 \%)$ & 53244 & 25967 \\
Language Learning & $0(0 \%)$ & 0 & $2(6.6 \%)$ & 25967 & \\
\hline
\end{tabular}

\subsection{RQ4: Which parameters determined the MOOCs' completion rates?}

The number of enrolled students was not the only significant indicator of MOOCs' attendance. In fact, it is not enough to attract students, it is more important to retain them. To further study retention, dependence between MOOCs' completion rates and other variables was analyzed. The dependent variable in this part of the analysis was the number of students who completed the course. A linear regression model that correlated the dependent variable with the number of enrolled students, course duration, assessment type and university type is represented in Tables 7 and 8. In this regression, two dummy variables were used that showed assessment type: peer grading and peer plus auto grading. The basic model without these variables was for auto grading courses. These types of courses prevailed on MOOC platforms. 
ANOVA analysis showed that the regression was statistically significant, with an adjusted R square of 0.425 . This justified the model as valid for interpreting its results. However, none of the variables, excluding the number of enrolled students, had significant betas. In other words, the coefficients in the model for these variables were not stable enough. They varied very much between different observations. However, none of these independent variables were excluded from the model, due to the fact that their exclusion reduced the significance level of the model.

Table 7

ANOVA for regression model

\begin{tabular}{lccccc}
\hline Model & Sum of Squares & Df & Mean Square & F & Sig. \\
\hline Regression & 452306539.925 & 5 & 90461307.985 & 12.844 & .000 \\
Residual & 528240028.544 & 75 & 7043200.381 & & \\
Total & 980546568.469 & 80 & & & \\
\hline
\end{tabular}

The average number of students who completed the course was 867.5. The only significant coefficient in the regression model was the number of enrolled students, however, its beta was 0.045 . Thus, for each additional 1,000 enrolled learners, just 45 students completed the course. In other words, smaller courses had higher completion rates. It was not unexpected that peer and peer plus auto assessments decreased the number of students who completed the course. According to the provided data, courses with these types of assessments had to have at least 12,000 and 1,100 enrolled students, respectively, to have anyone complete the course. MOOCs by non-top universities had higher completion rates. On average, courses by top universities were completed by 851.9 students fewer than courses by other universities. The variable for course duration was less stable. Course duration had a positive effect on the number students who completed the course. Because the maximum course duration was 14 weeks, the total effect could not be higher than several additional students. Thus, this variable was excluded from the results of the research.

Table 8

Coefficients for regression model

\begin{tabular}{lccccc}
\hline \multicolumn{7}{c}{ Unstandardized } \\
Coefficients & \multicolumn{2}{c}{$\begin{array}{c}\text { Standardized } \\
\text { Coefficients }\end{array}$} & & \\
Model & B & Std. Error & Beta & T & Sig. \\
\hline (Constant) & 867.5 & 603.2 & & 1.438 & 0.155 \\
Enrolment & 0.045 & 0.007 & 0.593 & 6.389 & 0 \\
Weeks & 0.323 & 1.027 & 0.028 & 0.315 & 0.754 \\
Peer & -1402.636 & 921 & -0.138 & -1.523 & 0.132 \\
Peer_Auto & -917.743 & 705.4 & -0.117 & -1.301 & 0.197 \\
Un_Type & 851.9 & 690.1 & 0.119 & 1.234 & 0.221 \\
\hline
\end{tabular}

Moreover, it is important to add that language courses (especially non-English ones), courses dedicated to nursing, child education, crime, copywriting and even theoretical management and psychology courses were the most unpopular (usually about 
1,000 enrolled students), however their average completion rate was high, at $27-35 \%$. Moreover, many of the most unpopular courses had the highest completion rates. Simultaneously, courses such as 'Introduction to Infographics and Data Visualization' and 'Introduction to Physical Actor Training' attracted about 2,000 students each with completion rates of about $7 \%$.

\section{Discussion}

The results of this study have shown that some of the previous results were no longer valid at the time when this article was written. However, the vast majority of previous results agreed with the current study. First of all, it is important to highlight that Evans and McIntyre (2014) estimated arts and humanities courses as courses that were not represented enough on Coursera and edX. In this research it has been shown that this MOOC category represented about $10 \%$ of all MOOCs, and a larger share (about 20\%) of the most popular courses in different time periods. Therefore, low course popularity and enrolment for a particular course could be explained by the inclusion of this course in the arts and humanities category.

Simultaneously, no 'Silicon Valley solutionism' was found (Morozov, 2013). In addition to data science and computer science courses representing from 24 to 37 percent of the total number of MOOCs on Coursera and edX, they represented about 40-50 percent of the most popular courses in different data series, while other all of the other categories were represented more or less equally. Moreover, computer courses were the second most popular according to the average number of enrolled students, and data science courses were only the fifth most popular, after math and logic, physical science and engineering, and arts and humanities courses. Their average enrolment was practically the same as social sciences courses. Undoubtedly, MOOCs started as a Silicon Valley project, and that has determined their origins. Computer and data science courses were the most popular for a long time and still have stayed some of the most popular in the world, however, their percentage among the most popular courses of the year significantly reduced in 2016. In that year, arts and humanities courses were the most popular ones. The high average enrolment of computer and data science courses was determined by the first courses available. However, new courses in these categories have had enrolments on par with MOOCs overall.

No data was found in this research that corroborated any of Giannella (2015), Johnston (2009) or Baggaley's (2014) results. MOOCs have attracted a lot of students every year. Many of them have not completed the MOOCs that they took. Some smaller courses had higher completion rates, however, and a rather stable dependence was found between the number of enrolled students and the number of students who completed the course. The more students enrolled in the course, the more students who would finish it. Thus, data could not prove Johnston (2009) and Baggaley's (2014) results. However, average completion rates were rather low, therefore the ideas of Giannella (2015) were also not proved.

Moreover, it is important to add that significant differences between the courses provided by the top universities and others were not found. Over a long period of time the top universities dominated MOOCs, however, $36 \%$ of the most popular courses of all time were provided by the other universities, and $70 \%$ in 2016. The other universities did not provide the sense of belonging to elite education. Thus, it could be concluded that Knox's ideas about the importance of this feeling in providing MOOCs and attracting students (2016b) should be tested further. Undoubtedly, this sense was extremely 
important at the beginning of MOOCs, however, it was not so obvious for current MOOC enrolment.

\section{Conclusion}

In this study, it was determined that different categories of courses were better represented on different platforms. All categories were represented enough to eliminate this as a dominant factor in the course enrolment process. Moreover, there were no significant differences between the most popular MOOCs in different categories. The same was true for university type (the top universities and others) and for MOOC platform. However, 64 percent of the most popular courses of all time were provided by top universities. There were four most popular categories (according to lists of the most popular MOOCs for different time periods): computer science, data science, business, and arts and humanities courses. Among fifty of all the time most popular MOOCs, the greatest percentage of them have been dedicated to computer science $(26 \%)$, followed by arts and humanities courses (20\%), and business courses (18\%). Just six courses have focused on data science (12\%). Despite this fact, the average number of enrolled students was not distributed in the same way. In addition, the most popular courses of all time were not the most popular courses in each year. There were many new courses that became extremely popular in each particular year. In all data series these four categories were represented more strongly than others. Moreover, among the most popular courses in the year 2016, just one course, in life sciences, was outside these categories.

The courses provided by top universities have attracted more students than those provided by other universities across all categories, excluding social sciences and language learning. However, the share of the most popular courses provided by the other universities has increased to $70 \%$. Thus, it can be concluded that it is not necessary to provide MOOCs from top universities to make them popular and to attract a lot of learners. It is much more important to present it on a well-known MOOC platform, such as Coursera or edX. The research showed that a course could become popular even without these platforms, but their usage increased the probability of success. Moreover, it was found that it was not necessary to choose any particular course category to create a popular MOOC with high student enrolment, due to the fact that each category had the potential to attract a lot of students, counted in thousands.

Nevertheless, enrolment does not mean taking the course, it just means registration. The number of students who completed the course was much lower than enrolment for every MOOC. However, there were several factors that could positively influence this parameter. First was university type. The number of students who completed courses by top universities was higher than for other universities. This cannot be explained by university ranking. The better universities with better ordinary courses had the higher rankings. These learning traditions and ordinary courses were transferred to the MOOCs. Thus, courses by the top universities had more students who completed them. The courses with higher completion rates usually are more well known. The simplistic fact that 'MOOCs by the top universities attracts more students', was not actually true. In this research the difference has been shown.

Undoubtedly, the number of enrolled students affected the number of students who completed the course. Typically, 4.5 students from each hundred completed the course. Many scientists criticized the MOOC format. However, the current study has shown that assessment by auto grading caused higher completion rates than other formats. Peer and peer plus auto assessments made courses more difficult and took more time, 
which decreased students' actual involvement. Thus, it could be concluded that the standard MOOC format, with auto grading, attracted more students who would really take the course, not just enrol in it.

\section{ORCID}

Sergey Kruchinin (iD https://orcid.org/0000-0002-9771-3378

\section{References}

Allen, I. E., \& Seaman, J. (2013). Changing course: Ten years of tracking online education in the United States. Newburyport, MA: Sloan Consortium. Retrieved from http://www.onlinelearningsurvey.com/reports/changingcourse.pdf

Baggaley, J. (2014). MOOCS: Digesting the facts. Distance Education, 35(2), 159-163.

Chandler, D. (2002). Technological determinism. Web essay, Media and Communications Studies, University of Aberystwyth, UK.

Chaturvedi, S., Goldwasser, D., \& Daumé III, H. (2014). Predicting instructor's intervention in MOOC forums. In Proceedings of the 52nd Annual Meeting of the Association for Computational Linguistics (Vol. 1, pp. 1501-1511).

Chernova, Y. (2013, July). New study sheds light on free online courses. The Wall Street Journal. Retrieved from http://blogs.wsj.com/venturecapital/2013/07/31/new-studysheds-light-on-free-online-courses/

Cirulli, F., Elia, G., \& Solazzo, G. (2017). A double-loop evaluation process for MOOC design and its pilot application in the university domain. Knowledge Management \& E-Learning (KM\&EL), 9(4), 433-448.

El Said, G. R. (2017). Understanding How learners use massive open online courses and why they drop out: Thematic analysis of an interview study in a developing country. Journal of Educational Computing Research, 55(5), 724-752.

Emanuel, E. L. (2013). Online education: MOOCs taken by educated few. Nature, 503, 342.

Evans, S., \& McIntyre, K. (2016). MOOCs in the humanities: Can they reach underprivileged students? Convergence, 22(3), 313-323.

Gaebel, M. (2013). MOOCs: Massive open online courses. European University Association (EUA) Occasional Papers Series. Retrieved from https://supporthere.org/sites/default/files/eua_occasional_papers_moocs_4.pdf

Giannella, E. (2015). Morality and the idea of progress in Silicon Valley. Berkeley Journal of Sociology. Retrieved from http://berkeleyjournal.org/2015/01/moralityand-the-idea-of-progress-in-silicon-valley

Johnston, R. (2009). Salvation or destruction: Metaphors of the Internet. First Monday 14(4): 5.

Jordan, K. (2013, March 11). MOOC completion rates: The data. KatyJordan. Retrieved from http://www.katyjordan.com/MOOCproject.html

Jordan, K. (2015). Massive open online course completion rates revisited: Assessment, length and attrition. The International Review of Research in Open and Distributed Learning, 16(3), 341-358.

Kanuka, H. (2008). Understanding e-learning technologies-in-practice. In T. Anderson (Ed.), The Theory and Practice of Online Learning (pp. 91-120). Edmonton, AB: AU Press.

Knox, J. (2014). Digital culture clash: "massive" education in the e-learning and digital cultures MOOC. Distance Education, 35(2), 164-177. 
Knox, J. (2016a). Posthumanism and the MOOC: Contaminating the subject of global education. Abingdon, UK: Routledge.

Knox, J. (2016b). Posthumanism and the MOOC: Opening the subject of digital education. Studies in Philosophy and Education, 35(3), 305-320.

Kobas, J. E. (2014). Measuring the success of scaleable open online courses. Performance Measurement and Metrics, 15(3), 145-162.

Liang, D., Jia, J., Wu, X., Miao, J., \& Wang, A. (2014). Analysis of learners' behaviors and learning outcomes in a massive open online course. Knowledge Management \& E-Learning (KM\&EL), 6(3), 281-298.

Maringe, F., \& Sing, N. (2014). Teaching large classes in an increasingly internationalising higher education environment: Pedagogical, quality and equity issues. Higher Education, 67(6), 761-782.

Morozov, E. (2013). To save everything, click here: Technology, solutionism, and the urge to fix problems that don't exist. London, UK: Penguin.

O'Connor, K. (2014). MOOCs, institutional policy and change dynamics in higher education. Higher Education, 68(5), 623-635.

Pappano, L. (2012, November 2). The year of the MOOC. The New York Times. Retrieved from http://www.nytimes.com/2012/11/04/education/edlife/massive-openonline-courses-are-multiplying-at-a-rapid-pace.html

Peters, G., \& Seruga, J. (2016). A supply sided analysis of leading MOOC platforms and universities. Knowledge Management \& E-Learning (KM\&EL), 8(1), 158-181.

Rodriguez, O. (2013). The concept of openness behind c and x-MOOCs (Massive Open Online Courses). Open Praxis, 5(1), 67-73.

The 50 most popular MOOCs of all time. (2015). OnlineCourseReport. Retrieved from https://www.onlinecoursereport.com/the-50-most-popular-moocs-of-all-time/

van der Sluis, F., Van der Zee, T., \& Ginn, J. (2017, April). Learning about learning at scale: Methodological challenges and recommendations. In Proceedings of the Fourth (2017) ACM Conference on Learning@ Scale (pp. 131-140). ACM.

Yuan, L., \& Powell, S. J. (2013). MOOCs and open education: Implications for higher education. JISC CETIS. Retrieved from https://espace.mmu.ac.uk/619735/1/MOOCs-and-Open-Education.pdf 


\section{Appendix I}

Table a

The most popular MOOCs of all time

\begin{tabular}{|c|c|c|c|c|}
\hline Courses & Category & University & MOOCs platform & Enrolment \\
\hline $\begin{array}{l}\text { Learning How to Learn: } \\
\text { Powerful mental tools to } \\
\text { help you master tough } \\
\text { subjects }\end{array}$ & $\begin{array}{l}\text { Arts and } \\
\text { humanities }\end{array}$ & UC San Diego & Coursera & 1192697 \\
\hline $\begin{array}{l}\text { Machine Learning: } \\
\text { Master the } \\
\text { Fundamentals }\end{array}$ & $\begin{array}{l}\text { Computer } \\
\text { science }\end{array}$ & $\begin{array}{l}\text { Stanford } \\
\text { University }\end{array}$ & Coursera & 1122031 \\
\hline R Programming & Data Science & $\begin{array}{l}\text { Johns Hopkins } \\
\text { University }\end{array}$ & Coursera & 952414 \\
\hline Introduction to Finance & Business & $\begin{array}{l}\text { University of } \\
\text { Michigan }\end{array}$ & Coursera & 846654 \\
\hline $\begin{array}{l}\text { The Data Scientist's } \\
\text { Toolbox }\end{array}$ & Data Science & $\begin{array}{l}\text { Johns Hopkins } \\
\text { University }\end{array}$ & Coursera & 828837 \\
\hline $\begin{array}{l}\text { Think Again: How to } \\
\text { Reason and Argue }\end{array}$ & $\begin{array}{l}\text { Arts and } \\
\text { humanities }\end{array}$ & Duke University & Coursera & 775717 \\
\hline Algorithms: Part 1 & Data Science & $\begin{array}{l}\text { Princeton } \\
\text { University }\end{array}$ & Coursera & 751089 \\
\hline $\begin{array}{l}\text { Developing Innovative } \\
\text { Ideas for New } \\
\text { Companies: The First } \\
\text { Step in Entrepreneurship }\end{array}$ & Business & $\begin{array}{l}\text { University of } \\
\text { Maryland, } \\
\text { College Park }\end{array}$ & Coursera & 736347 \\
\hline $\begin{array}{l}\text { Understanding IELTS: } \\
\text { Techniques for English } \\
\text { Language Tests }\end{array}$ & $\begin{array}{l}\text { Language } \\
\text { Learning }\end{array}$ & British Council & FutureLearn & 690567 \\
\hline $\begin{array}{l}\text { Programming Mobile } \\
\text { Applications for } \\
\text { Android Handheld } \\
\text { Systems - Part } 1\end{array}$ & $\begin{array}{l}\text { Computer } \\
\text { science }\end{array}$ & $\begin{array}{l}\text { University of } \\
\text { Maryland }\end{array}$ & Coursera & 678451 \\
\hline Cryptography I & $\begin{array}{l}\text { Computer } \\
\text { science }\end{array}$ & $\begin{array}{l}\text { Stanford } \\
\text { University }\end{array}$ & Coursera & 674404 \\
\hline $\begin{array}{l}\text { Programming for } \\
\text { Everybody (Getting } \\
\text { Started with Python) }\end{array}$ & $\begin{array}{l}\text { Computer } \\
\text { science }\end{array}$ & $\begin{array}{l}\text { University of } \\
\text { Michigan }\end{array}$ & Coursera & 657068 \\
\hline Social Psychology & $\begin{array}{l}\text { Social } \\
\text { Sciences }\end{array}$ & $\begin{array}{l}\text { Wesleyan } \\
\text { University }\end{array}$ & Coursera & 645568 \\
\hline $\begin{array}{l}\text { Introduction to Public } \\
\text { Speaking }\end{array}$ & $\begin{array}{l}\text { Social } \\
\text { Sciences }\end{array}$ & $\begin{array}{l}\text { University of } \\
\text { Washington }\end{array}$ & Coursera & 616208 \\
\hline Model Thinking & $\begin{array}{l}\text { Math and } \\
\text { Logic }\end{array}$ & $\begin{array}{l}\text { University of } \\
\text { Michigan }\end{array}$ & Coursera & 582200 \\
\hline
\end{tabular}


An Introduction to Interactive Programming in Python

Introduction to

Philosophy

science

Rice University Coursera

581043

Algorithms: Design and

Analysis, Part 1

Introduction to

Arts and

University of

humanities

Edinburgh

Coursera

550000

Data Science

Stanford

Computer Science

Inspiring Leadership

through Emotional

Intelligence

Game Theory

Computer

University

Coursera

548641

science

Udacity

515476

Arts and

Case Western

humanities

Reserve

Coursera

494369

Math and Stanford

Logic

University

Coursera

474148

Calculus One

Math and

Ohio State

Logic

University

Coursera

454410

Competitive Strategy

Business

Ludwig-

Maximilians-

Coursera

430582

München (LMU)

Write101x: English

Grammar and Style

Language

University of

Learning

Queensland

edX

414432

IELTSx: IELTS

Academic Test

Preparation

Language

University of

Learning

Queensland

edX

355026

Introduction to

Computer Science

Computer

Harvard

Exploring English:

Language and Culture

science

University

Language

Learning

British Council

edX

348476

Think101x: The Science

of Everyday Thinking

Data Analysis and

Statistical Inference

Arts and

humanities

University of

Queensland

FutureLearn

326093

Data Science

Duke University

edX

304694

Gamification

Business

University of

Pennsylvania /

Coursera

Physical

Circuits and Electronics

Science and

MIT

edX

229813

Creativity, Innovation and Change

Engineering

Business

Penn State

Coursera

220000

A Beginner's Guide to

Social

Irrational Behavior

Sciences

Duke University

Coursera

217331

Web Development: How to Build a Blog

Computer

science

Learn to Program: The

Computer

University of

Udacity

217322

198566 


\begin{tabular}{|c|c|c|c|c|}
\hline Fundamentals & science & Toronto & & \\
\hline $\begin{array}{l}\text { Greek and Roman } \\
\text { Mythology }\end{array}$ & $\begin{array}{l}\text { Arts and } \\
\text { humanities }\end{array}$ & $\begin{array}{l}\text { University of } \\
\text { Pennsylvania }\end{array}$ & Coursera & 180000 \\
\hline Startup Engineering & $\begin{array}{l}\text { Computer } \\
\text { science }\end{array}$ & $\begin{array}{l}\text { Stanford } \\
\text { University }\end{array}$ & Coursera & 170305 \\
\hline $\begin{array}{l}\text { Computational } \\
\text { Investing, Part I }\end{array}$ & Business & $\begin{array}{l}\text { Georgia Institute } \\
\text { of Technology }\end{array}$ & Coursera & 170000 \\
\hline Financial Markets & Business & Yale University & Coursera & 161959 \\
\hline $\begin{array}{l}\text { Introduction to Artificial } \\
\text { Intelligence }\end{array}$ & $\begin{array}{l}\text { Computer } \\
\text { science }\end{array}$ & $\begin{array}{l}\text { Stanford } \\
\text { University }\end{array}$ & Coursera & 160000 \\
\hline $\begin{array}{l}\text { Introduction to } \\
\text { Computer Science and } \\
\text { Programming }\end{array}$ & $\begin{array}{l}\text { Computer } \\
\text { science }\end{array}$ & MIT & edX & 157431 \\
\hline $\begin{array}{l}\text { Introduction to Financial } \\
\text { Accounting }\end{array}$ & Business & $\begin{array}{l}\text { University of } \\
\text { Pennsylvania / } \\
\text { Wharton }\end{array}$ & Coursera & 155516 \\
\hline $\begin{array}{l}\text { Modern \& } \\
\text { Contemporary American } \\
\text { Poetry }\end{array}$ & $\begin{array}{l}\text { Arts and } \\
\text { humanities }\end{array}$ & $\begin{array}{l}\text { University of } \\
\text { Pennsylvania }\end{array}$ & Coursera & 140000 \\
\hline Data Analysis & Data Science & $\begin{array}{l}\text { Johns Hopkins } \\
\text { Bloomberg } \\
\text { School }\end{array}$ & Coursera & 102000 \\
\hline $\begin{array}{l}\text { Introduction to } \\
\text { Computer Science and } \\
\text { Programming Using } \\
\text { Python }\end{array}$ & $\begin{array}{l}\text { Computer } \\
\text { science }\end{array}$ & MIT & edX & 98688 \\
\hline $\begin{array}{l}\text { The Future of } \\
\text { Storytelling }\end{array}$ & $\begin{array}{l}\text { Arts and } \\
\text { humanities }\end{array}$ & $\begin{array}{l}\text { University of } \\
\text { Applied Sciences } \\
\text { Potsdam }\end{array}$ & iversity & 92957 \\
\hline $\begin{array}{l}\text { Science and Cooking: } \\
\text { From Haute Cuisine to } \\
\text { Soft Matter Science }\end{array}$ & $\begin{array}{l}\text { Arts and } \\
\text { humanities }\end{array}$ & $\begin{array}{l}\text { Harvard } \\
\text { University }\end{array}$ & edX & 92045 \\
\hline $\begin{array}{l}\text { Introduction to } \\
\text { Philosophy: God, } \\
\text { Knowledge, and } \\
\text { Consciousness }\end{array}$ & $\begin{array}{l}\text { Arts and } \\
\text { humanities }\end{array}$ & MIT & edX & 89183 \\
\hline $\begin{array}{l}\text { Introduction to } \\
\text { Operations Management }\end{array}$ & Business & $\begin{array}{l}\text { University of } \\
\text { Pennsylvania / } \\
\text { Wharton }\end{array}$ & Coursera & 87000 \\
\hline $\begin{array}{l}\text { Introduction to } \\
\text { Mathematical Thinking }\end{array}$ & $\begin{array}{l}\text { Math and } \\
\text { Logic }\end{array}$ & $\begin{array}{l}\text { Stanford } \\
\text { University }\end{array}$ & Coursera & 86230 \\
\hline
\end{tabular}


Table b

The most popular MOOCs of 2014

\begin{tabular}{|c|c|c|c|}
\hline Courses & Category & University & MOOCs platform \\
\hline $\begin{array}{l}\text { Developing Innovative Ideas } \\
\text { for New Companies: The } \\
\text { First Step in Entrepreneurship }\end{array}$ & Business & $\begin{array}{l}\text { University of } \\
\text { Maryland, } \\
\text { College Park }\end{array}$ & Coursera \\
\hline Introduction to Statistics & $\begin{array}{l}\text { Data } \\
\text { Science }\end{array}$ & $\begin{array}{l}\text { Stanford } \\
\text { University }\end{array}$ & Udacity \\
\hline $\begin{array}{l}\text { Learning How to Learn: } \\
\text { Powerful mental tools to help } \\
\text { you master tough subjects }\end{array}$ & $\begin{array}{l}\text { Arts and } \\
\text { humanities }\end{array}$ & UC San Diego & Coursera \\
\hline $\begin{array}{l}\text { Introduction to Computer } \\
\text { Science }\end{array}$ & $\begin{array}{l}\text { Computer } \\
\text { science }\end{array}$ & $\begin{array}{l}\text { University of } \\
\text { Virginia }\end{array}$ & Udacity \\
\hline $\begin{array}{l}\text { Principles of Project } \\
\text { Management }\end{array}$ & Business & $\begin{array}{l}\text { Polytechnic } \\
\text { West }\end{array}$ & Open2Study \\
\hline $\begin{array}{l}\text { Introduction to Computer } \\
\text { Science }\end{array}$ & $\begin{array}{l}\text { Computer } \\
\text { science }\end{array}$ & $\begin{array}{l}\text { Harvard } \\
\text { University }\end{array}$ & edX \\
\hline $\begin{array}{l}\text { Inspiring Leadership through } \\
\text { Emotional Intelligence }\end{array}$ & $\begin{array}{l}\text { Arts and } \\
\text { humanities }\end{array}$ & $\begin{array}{l}\text { Case Western } \\
\text { Reserve } \\
\text { University }\end{array}$ & Coursera \\
\hline Introduction to Finance & Business & $\begin{array}{l}\text { University of } \\
\text { Michigan }\end{array}$ & Coursera \\
\hline Strategic Management & Business & - & Open2Study \\
\hline R Programming & $\begin{array}{l}\text { Data } \\
\text { Science }\end{array}$ & $\begin{array}{l}\text { Johns Hopkins } \\
\text { University }\end{array}$ & Coursera \\
\hline
\end{tabular}

Table c

The most popular MOOCs of 2015 at Coursera platform

\begin{tabular}{|c|c|c|c|}
\hline Courses & Category & University & MOOCs platform \\
\hline $\begin{array}{l}\text { Learning How to Learn: Powerful } \\
\text { mental tools to help you master } \\
\text { tough subjects }\end{array}$ & $\begin{array}{l}\text { Arts and } \\
\text { humanities }\end{array}$ & $\begin{array}{l}\text { UC San } \\
\text { Diego }\end{array}$ & Coursera \\
\hline Mastering Data Analysis in Excel & Data Science & $\begin{array}{l}\text { Duke } \\
\text { University }\end{array}$ & Coursera \\
\hline $\begin{array}{l}\text { Programming for Everybody } \\
\text { (Getting Started with Python) }\end{array}$ & $\begin{array}{l}\text { Computer } \\
\text { science }\end{array}$ & $\begin{array}{l}\text { University of } \\
\text { Michigan }\end{array}$ & Coursera \\
\hline $\begin{array}{l}\text { Machine Learning: Master the } \\
\text { Fundamentals }\end{array}$ & $\begin{array}{l}\text { Computer } \\
\text { science }\end{array}$ & $\begin{array}{l}\text { Stanford } \\
\text { University }\end{array}$ & Coursera \\
\hline R Programming & Data Science & $\begin{array}{l}\text { Johns } \\
\text { Hopkins } \\
\text { University }\end{array}$ & Coursera \\
\hline
\end{tabular}




\begin{tabular}{|c|c|c|c|}
\hline The Data Scientist's Toolbox & Data Science & $\begin{array}{l}\text { Johns } \\
\text { Hopkins } \\
\text { University }\end{array}$ & Coursera \\
\hline $\begin{array}{l}\text { Tibetan Buddhist Meditation and } \\
\text { the Modern World }\end{array}$ & $\begin{array}{l}\text { Arts and } \\
\text { humanities }\end{array}$ & $\begin{array}{l}\text { University of } \\
\text { Virginia }\end{array}$ & Coursera \\
\hline $\begin{array}{l}\text { An Introduction to Interactive } \\
\text { Programming in Python }\end{array}$ & $\begin{array}{l}\text { Computer } \\
\text { science }\end{array}$ & $\begin{array}{l}\text { Rice } \\
\text { University }\end{array}$ & Coursera \\
\hline $\begin{array}{l}\text { Successful Negotiation: Essential } \\
\text { Strategies and Skills }\end{array}$ & Business & $\begin{array}{l}\text { University of } \\
\text { Michigan }\end{array}$ & Coursera \\
\hline $\begin{array}{l}\text { Introduction to Financial } \\
\text { Accounting }\end{array}$ & Business & $\begin{array}{l}\text { University of } \\
\text { Pennsylvania } \\
\text { / Wharton }\end{array}$ & Coursera \\
\hline
\end{tabular}

\section{Table d}

The most popular MOOCs of 2016

\begin{tabular}{|c|c|c|c|}
\hline Courses & Category & University & MOOCs platform \\
\hline Cryptography I & $\begin{array}{l}\text { Computer } \\
\text { science }\end{array}$ & $\begin{array}{l}\text { Stanford } \\
\text { University }\end{array}$ & Coursera \\
\hline Nutrition and Health: Food Safety & Life sciences & $\begin{array}{l}\text { Wageningen } \\
\text { university }\end{array}$ & edX \\
\hline Writing for the Web & $\begin{array}{l}\text { Language } \\
\text { Learning }\end{array}$ & $\begin{array}{l}\text { The } \\
\text { university of } \\
\text { Melbourne }\end{array}$ & Open2Study \\
\hline The Science of Happiness & $\begin{array}{l}\text { Arts and } \\
\text { humanities }\end{array}$ & $\begin{array}{l}\text { Berkley } \\
\text { University of } \\
\text { California }\end{array}$ & edX \\
\hline Introduction to Game Design & $\begin{array}{l}\text { Social } \\
\text { Sciences }\end{array}$ & $\begin{array}{l}\text { California } \\
\text { Institute of } \\
\text { the Arts }\end{array}$ & Coursera \\
\hline R Programming & Data Science & $\begin{array}{l}\text { Johns } \\
\text { Hopkins } \\
\text { University }\end{array}$ & Coursera \\
\hline $\begin{array}{l}\text { Learning How to Learn: Powerful } \\
\text { mental tools to help you master } \\
\text { tough subjects }\end{array}$ & $\begin{array}{l}\text { Arts and } \\
\text { humanities }\end{array}$ & $\begin{array}{l}\text { UC San } \\
\text { Diego }\end{array}$ & Coursera \\
\hline $\begin{array}{l}\text { Developing Innovative Ideas for } \\
\text { New Companies: The First Step in } \\
\text { Entrepreneurship }\end{array}$ & Business & $\begin{array}{l}\text { University of } \\
\text { Maryland, } \\
\text { College Park }\end{array}$ & Coursera \\
\hline Conversational English Skills & $\begin{array}{l}\text { Language } \\
\text { Learning }\end{array}$ & $\begin{array}{l}\text { Tsinghua } \\
\text { University }\end{array}$ & edX \\
\hline $\begin{array}{l}\text { Programming for Everybody } \\
\text { (Getting Started with Python) }\end{array}$ & $\begin{array}{l}\text { Computer } \\
\text { science }\end{array}$ & $\begin{array}{l}\text { University of } \\
\text { Michigan }\end{array}$ & Coursera \\
\hline
\end{tabular}

